\title{
Areas of placement and specialization in the development of agricultural production management in Russia
}

\author{
Alexander Semkin ${ }^{1, *}$, Lydia Silaeva ${ }^{1}$, Evgeny Voronin $^{1}$, and Alexander Pyatinsky ${ }^{1}$ \\ ${ }^{1}$ Federal Research Center of Agrarian Economy and Social Development of Rural Areas - All- \\ Russian Research Institute of Agricultural Economics, Khoroshevskoe highway str., 35, bld. 2, \\ Moscow, 123007, Russia
}

\begin{abstract}
The article discusses the issues of strategic development of the management of accommodation and specialization of the municipal level agricultural entities, where the main threats associated with the justification of the strategic management object at the municipal level, the assessment of its state, trends and prospects of functioning, starting with the initial link of economic interactions of agricultural organizations, as well as the possibility of the formation of agricultural production, implementation and transformation of its potential, with the highlighting the number of features corresponding to a certain relationship at a given level are determined. Priority principles are substantiated with the choice of the main strategic areas for more efficient use of existing opportunities, as a result of which a new or improved agricultural product will be created. The transformation of the management strategy of agricultural economic entities in the field of accommodation and specialization was carried out, and its organizational and structural model was presented which will have a certain sequence and interaction at the municipal level.
\end{abstract}

\section{Introduction}

The development of strategic management of business entities in the field of accommodation and specialization of agricultural production at the world level and in Russia, first of all, depends on the functioning of the agricultural sector of the economy itself, as well as on the formation of organizational and economic structures of business entities. Therefore, in order to increase the efficiency of agricultural production, its integration into large agricultural organizations (agricultural holdings, agricultural clusters, etc.) has become a main trend. In this regard, as shown by many years of experience, one of the main conditions for increasing the efficiency and competitiveness of domestic agricultural production shall be the implementation of measures to implement the Spatial Development Strategy of the Russian Federation for the period until 2025, approved by order of the Government of the Russian Federation dated February 13, 2019 No. 207-r and developed on the basis of the Federal Law "On Strategic Planning in the Russian

\footnotetext{
*Corresponding author: vera_306@mail.ru
} 
Federation" dated June 28, 2014 No. 172-FZ, where it is ascertained that spatial development contributes to the improvement of the territorial organization of production and the agricultural economy as a whole through the rational accommodation and specialization of agricultural production, which are one of the important factors in conducting expanded reproduction, and will also contribute to obtaining additional net income, efficient use of basic, circulating and financial assets, timely and high-quality use of other types of resources.

\section{Materials and Methods}

In carrying out the theoretical and methodological foundations of this research article, the following research methods were used: economic and statistical, institutional analysis, abstract and logical, comparative analysis, systemic and institutional approaches. The information and analytical base of the article was the scientific efforts of domestic and foreign agricultural scientists on the issue of managing business entities in the field of accommodation and specialization of agricultural production, the development program for agriculture and AIC as a whole, as well as regulatory legal acts of executive and legislative authorities of administration at various levels, statistical data, Internet resources and other sources.

\section{Results}

The territorial division of labor is designed to more effectively contribute to both the rational accommodation of agricultural production in certain areas (municipalities), and the development of specialization in these areas, as well as the introduction of innovative and investment novations to promote and deepen agricultural production, which will have a significant impact on the formation of the agricultural economy [1].

Having drawn an analogy of the definitions of various authors in the scientific literature related to strategic development using elements of efficient accommodation and specialization of production, we need to highlight the main essence of the conceptual apparatus of the agricultural municipal strategy, which is a scientifically grounded organizational and production concept based on elements of planning and forecasting actions of agricultural organizations. It shall reflect the specific directions of the formation, development and implementation of an appropriate strategy that are necessary throughout the entire life cycle, and shall also determine how and under what certain conditions elements of self-organization of business processes fit into it, due to the need for dynamic adaptation to changes in the external environment. All these are extremely important issues related to the strategic management of agricultural organizations which shall be considered as the integrity of commercial and economic management at the municipal level [2].

In the course of study of strategic management of accommodation and specialization at the municipal level, starting with the functioning of the initial link of economic interactions of an agricultural organization, as well as the possibility of forming production, sales and transformation of manufactured products at this level, it is necessary to highlight a number of features of the relevant interactions and relationships [3-4].

First of all, it is necessary to consider the intensity of functioning within the sectoral balance and the formation of functional relationships between agricultural sub-sectors where direct interacting relationships are implemented between the efficiency of using all types of resource potentials and the ability of some business entities to carry out management activities by other business objects. 
Secondly, a huge degree of functional responsibility in the formation of the production of municipal agricultural products for both the district (municipal) community and the country as a whole, while everything shall be determined by the need to use a number of areas related to stimulating, regulatory and coordinating tools from various tiers of authority.

Analyzing the first of these provisions, it shall be noted that this assumption only under certain conditions will have a positive effect on obtaining certain results of agricultural activity, which include: analysis of production cycles, channels of formation and movement of the municipal product, which should reflect the reliability and uniformity of the received the effect of using the resource potential. Otherwise, with low use of this potential by production entities at any of the stages in the reproduction chain of the municipal level: initial - in production in an agricultural organization, intermediate - in processing, at the final stage - in marketing implementation, the result of using strategic elements management will be negligible.

Weak integration at the level of municipal and economic management in the agricultural sector, the absence of a mechanism for effective interaction and coordination, as well as a common understanding of strategic goal setting, all this leads to an imbalance in the reproduction process, nullifies the effectiveness of management decisions in each individual element with increase in transaction costs.

And vice versa, rationally considered and effectively planned strategic directions of municipal agriculture management will be distinguished by close and mutually beneficial intra-industry relationships, a balanced production and commercial and economic management structure, as well as an optimally formulated development strategy for accommodation and specialization, based on principles such as more efficient placement and specialization of agricultural production, considering all types of potential (natural and climatic, socio-economic, organizational and production, personnel, etc.), considering the main factors of territorial features, the fair distribution of functions and powers at all managerial levels related to social and economic development, balanced resettlement of rural areas and integrated approach to the formation of state support for municipal agriculture and rural development [5].

When forming strategic management of the accommodation and specialization of agricultural entities, not only pros and cons shall be considered, but also the opportunities of both agricultural business and rural areas at the municipal level. All this is largely caused by the lack of an effective strategic management structure at the state and economic levels of the municipal agricultural development. Therefore, as a result of the study, it is emphasized that without the use of state (municipal) levers of regulation, where the fundamental function is state support and coordination in the field of program-oriented management, and agricultural organizations shall function in conditions of interconnection with the external environment; taking all of this into account, adaptive potential for developing and implementing the optimal strategy for municipal development and management in the field of agricultural sector will be formed more effectively (Fig. 1).

The pace of sustainable social and economic development of the municipal agricultural sector in the field of accommodation and specialization, which effectiveness must be ensured as soon as possible, can only be achieved through innovation and investment trajectory, while it is necessary to fundamentally change the organizational, economic and production conditions for the formation of production with the introduction of digital intensification based on the use of modern high-end technologies. All this is possible only with the introduction of an adaptive system of strategic planning and forecasting, in which it is necessary to strive not only to realize the various potentials available in the field of agricultural production, but also to deepen them both in quantitative and qualitative performance [6-7]. Due to the fact that the final municipal agricultural product is an 
economic orientation and is the target function of agricultural business, the basis for fulfilling strategic tasks by an agricultural organization with a choice of the main strategic directions will be more efficient use of the potential of existing opportunities, as a result of which a new or improved agricultural product shall be created with the highest consumer value and which shall be identified as a municipal agricultural product strategic development with the use of more efficient distribution and specialization of agricultural production.

\begin{tabular}{|c|c|c|c|}
\hline $\begin{array}{l}\text { Development } \\
\text { and } \\
\text { determination of } \\
\text { agreement on } \\
\text { the } \\
\text { implementation } \\
\text { of the strategy } \\
\text { by all } \\
\text { participants in } \\
\text { the process }\end{array}$ & $\begin{array}{l}\text { Setting } \\
\text { objectives for } \\
\text { the strategic } \\
\text { approach of } \\
\text { agricultural } \\
\text { entities }\end{array}$ & $\begin{array}{l}\text { Assessment and } \\
\text { analysis of the } \\
\text { internal and } \\
\text { external } \\
\text { environment, } \\
\text { correlation of } \\
\text { investment and } \\
\text { innovation plans }\end{array}$ & $\begin{array}{l}\text { Management } \\
\text { survey of pros } \\
\text { and cons in the } \\
\text { accommodation } \\
\text { and } \\
\text { specialization of } \\
\text { production }\end{array}$ \\
\hline $\begin{array}{l}\text { Assessment of the } \\
\text { implementation } \\
\text { of the strategy in } \\
\text { managing the } \\
\text { accommodation } \\
\text { and specialization } \\
\text { of production } \\
\text { with the } \\
\text { formation of a } \\
\text { feedback system }\end{array}$ & $\begin{array}{l}\text { Implementation } \\
\text { of the strategy } \\
\text { with the } \\
\text { development of } \\
\text { leadership in the } \\
\text { field of } \\
\text { agricultural } \\
\text { production }\end{array}$ & $\begin{array}{l}\text { The choice of } \\
\text { management } \\
\text { development } \\
\text { strategy in the } \\
\text { field of } \\
\text { accommodation } \\
\text { and } \\
\text { specialization }\end{array}$ & $\begin{array}{l}\text { Analysis of } \\
\text { strategic } \\
\text { alternatives and } \\
\text { risks in areas } \\
\text { (organizational, } \\
\text { motivational, } \\
\text { informational, } \\
\text { etc.) }\end{array}$ \\
\hline
\end{tabular}

Fig. 1. Scheme of the process of management strategy of economic entities in the field of accommodation and specialization of agricultural production at the municipal level, Source: authordeveloped

On the one hand, a logical analysis suggests that any strategy at the municipal level is able to determine and form only the main directions of agricultural production and economic development, but it will not be able to anticipate possible changes in the social, economic and production field and at the same time highlight obviously specific practical recommendations, which implementation will take place in a strictly designated place, at a specific time and with the filling of certain target indicators.

On the other hand, in any strategy, there must be a certain degree of specificity associated with certain areas of the functioning and development of the agricultural organization, and there shall also be certain visions of the framework for economic functioning, that is, specific indicators (growth points) of the upper and lower boundaries of agribusiness, in addition to all this, the strategy shall reflect the functional dependence and usefulness of the agricultural organization in the field of state and economic management at the municipal level.

It shall also be noted that the transformation of municipal strategic management with the development of elements of placement and specialization as a whole meets the basic criteria of the theory and self-organization of "synergetics", where in the case of fairly minor changes an irreversible reaction can occur that will necessarily lead to the transformation of the basic structure and its management as a whole, and therefore a new 
(or improved) cycle of development of the agricultural organization will necessarily begin. Therefore, if the deviations are significant and the dispersion of external or internal fluctuations exceeds a critical threshold, then this structure will face a choice of the option of irreversible disorganization, where in this case it can use an alternative strategy and move to a higher management level. In this regard, the management and development strategy using more efficient accommodation and specialization of agricultural production naturally evolves and can adapt to various changes, while ensuring the efficient functioning (survival) of the agricultural organization and the sustainable development of sub-sectors of the municipal AIC $[8,9]$.

Based on the above, it shall be noted that the transformation of the strategy of municipal management of economic entities in the field of accommodation and specialization will have a certain sequence of interaction given in Figure 2.

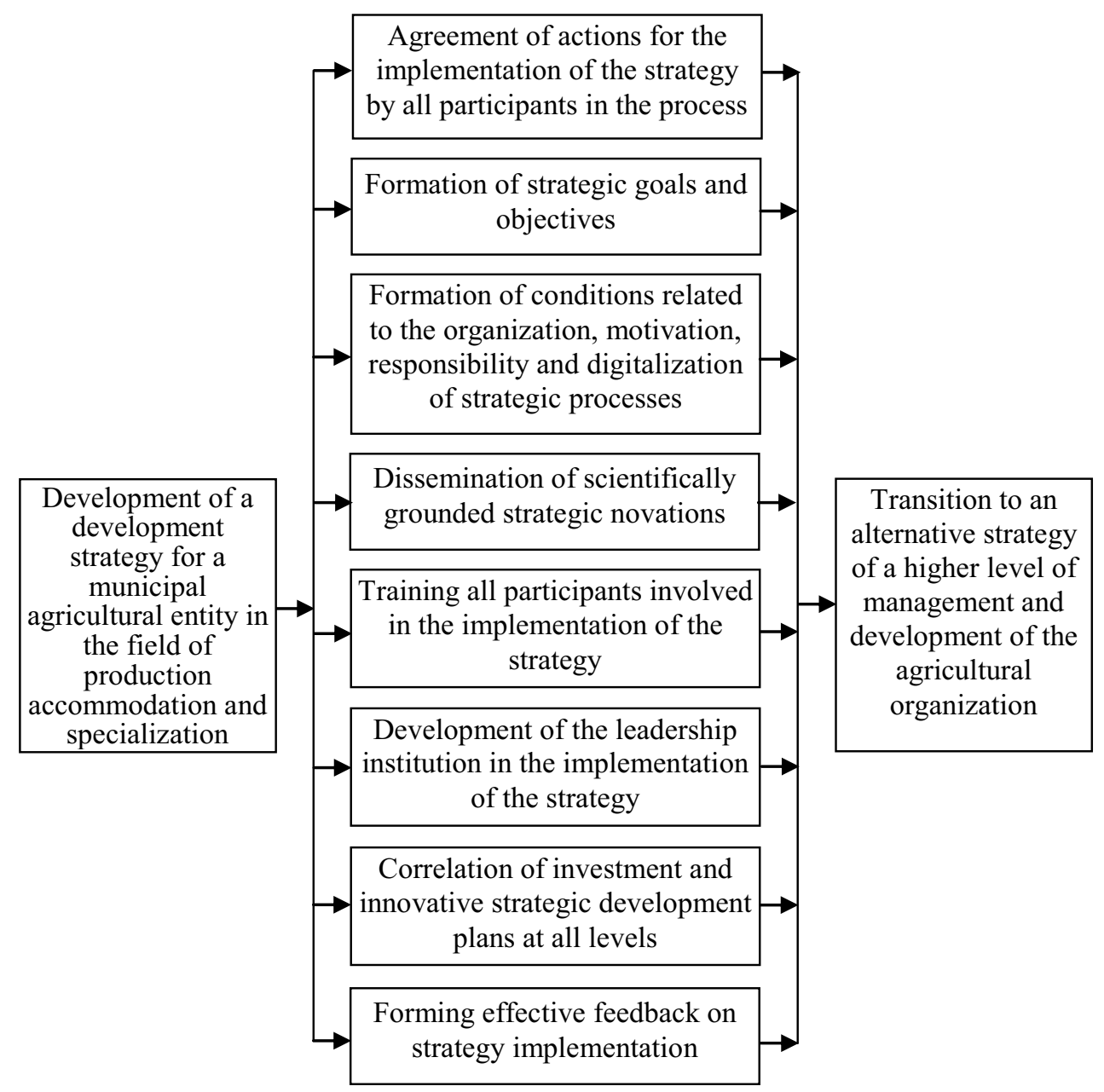

Fig. 2. Transformation of the strategy of municipal management of economic agricultural entities in the field of accommodation and specialization, Source: author-developed

\section{Discussion}


Here, a certain sequence of strategic interactions shall be carried out with the structural transformation of the strategy of municipal management of economic entities in the field of accommodation and specialization related to external and internal factors that need to be built into such a system of indicators that must meet certain conditions of a balanced compromise, as well as effective adoption and implementation of managerial strategic decisions [10-11].

Considering the above, we can conclude that the effective functioning of the municipal strategic management with the development of elements of accommodation and specialization shall be formed considering the factors such as:

- the use of a set of laws, regularities and principles with the definition of cause-effect relationships between objects and subjects of agriculture, as well as processes in the field of production, economic and social relations associated with the development trend of organizational, structural and functional interactions at the municipal level;

- the strategic management elements that were formed during the implementation of the development strategy in the municipal agricultural production shall undergo evolutionary transformations related to economic and economic sectors, as integrated systems for the management of effective business functions, development and reproductive cycle management by agricultural business structures;

- comprehensive support of the interests of agricultural business and agricultural social medium by state (municipal) authorities, as well as commercial and economic management at various levels, which shall be associated with the process of consolidating efforts to carry out the reproduction cycle of production, economic and human capital, as well as social responsibility for rural development [12];

- highlighting as an object of the municipal government of the agricultural region, which shall be formed within the spatial economic development in the form of a geographically integrated system of relationships, the specificity of which shall be formed by transforming the strategy of municipal management of economic entities and factors of improving the reproductive process of agriculture of the municipality;

- the formation of a single production, economic and information and analytical space by business entities at the municipal level with different organizational and legal forms of ownership, various production lines and concentration of agricultural capital, as well as the maximum use and involvement of all types of resource support;

- organization of effective relationships in the production, economic and social space of municipal agriculture based on the development of integrated, cooperative and other forms of management (food sub-complexes, food clusters, industry unions and associations, etc.) that contribute to the strategic management of the municipal level [13];

- development of the economic and economic mechanism of interaction between the state (municipal) administration and the agricultural business in the field of effective formation of public and private partnerships and the creation of conditions for increasing the social responsibility of the state and agribusiness for the effective functioning of rural territories and the population living on them;

- proportionality and balance of municipal agriculture of both the production and economic system, and the system of territorial and sectoral formation;

- the implementation of elements of the development strategy of the municipal level using mechanisms and approvals in the field of accommodation and specialization shall correspond to the goals and objectives of strategic management and development at the regional and federal levels;

- the effective formation and increase of responsibility for the organization of the territorial and branch commercial and economic management of the municipal level, which is associated with the spatial ordering of its structural elements and their effective interactions with other territorial entities in the interests of the development of the agricultural industry; 
- the need for institutional changes that determine the laws of the game in the formation and development of social and economic programs at the municipal level;

- assessment of multifunctional sub-sectors, the complexity and multidimensional nature of municipal agriculture and its production shall be considered in the formation of strategic plans for the development of the territorial-sectoral system of various tiers of authority;

- development of a mechanism for diversification of the municipal economy due to the complexity and heterogeneity of production processes in agriculture with the involvement of other organizational forms of management, such as the development of rural tourism, national crafts, cooperation and integration of agricultural production, which will focus on the growth of rural employment and increase its profitability.

The possibilities of state regulation of some areas of agricultural production development, including by increasing the territorial accommodation and the level of specialization, in modern business conditions are often crucial. At the same time, state regulation is understood as the economic and organizational impact on the production, processing and sale of agricultural products. State regulation is a system of legislative, executive and control measures and, in essence, is one of the most important strategic management functions performed by the Government of the Russian Federation and the Ministry of Agriculture of the Russian Federation [14, 15].

State regulation is often identified with state support, which is practically a part or type of state regulation.

State regulation of agricultural production in the field of accommodation and specialization in general is carried out mainly by economic instruments:

- prices - target, guaranteed and others;

- taxes - preferential taxation and SAT;

- loans - preferential;

- budget financing: subsidies, subventions, loans, compensations, etc.;

- interventions - purchasing and commodity, mainly grain in state funds;

- crop insurance with payment of $50 \%$ of the insurance premium;

- customs duties on export and import of agricultural products.

State support is provided in the following areas of production development:

- increase soil fertility and the involvement of previously arable land in agricultural circulation, including for the territorial distribution and specialization of agricultural products, especially for corn, durum wheat, etc.;

- development of line breeding and seed production;

- development of agricultural production in greenhouses;

- development of irrigated agriculture;

- development of livestock breeding, dairy and beef cattle breeding;

- the development of deep processing of agricultural raw materials, especially wheat and corn;

- provision of grants to newly created peasant (private) farms;

- creation and development of agricultural cooperation and integration and other areas.

The results of state regulation and support are the proportional economic development of agricultural production, increasing labor productivity, ensuring a balance of income and expenditure in agriculture, and most importantly, achieving food security in the country, in particular, the level of $95 \%$ for grain at $95 \%$ is actually reached, as well as improving the provision of the population with high-quality food products of domestic production.

The analysis of the management system of agricultural organizations in the field of accommodation and specialization of agricultural production shows their different target areas which ensures that only a certain part of the strategic goals for the development of sub-sectors at the municipal level are solved and the whole bulk of the essential paramount as well as strategic tasks of the effective functioning of business entities. 


\section{Conclusion}

There are several approaches to resolve this issue.

The first is that the basis for the development strategy of agricultural organizations shall be the conceptual elements of effective marketing. This is caused by the fact that nowadays the main direction in the production chain of agricultural production is logistics and the sale of finished products.

The second approach determines that the municipal agricultural business shall more effectively use the motivational mechanism associated with the availability of property, where the financial and economic support of agricultural production primarily depends on well-designed, carefully planned and efficiently used satellites of ownership.

The third approach formulates that with a limited financial and investment orientation of all types of resource potential of agricultural organizations, as well as using a mechanism for real risk assessment and development opportunities for strategic segments of the functioning of the municipal agricultural sector, technical reequipment shall be preferred, with particular attention to the development of high-tech and energy-saving manufacturing technologies using digital elements.

In the fourth approach, it is necessary to emphasize, when applying the conceptual apparatus of effective strategic management, to use effective competitiveness management for these purposes, due to the fact that at the present stage it is more suitable in terms of meaning and also corresponds to the content and scope of the organizational and production activities of agricultural organizations in the following areas: defines broader production and economic activity, more efficiently forms the structures of management and marketing sectors, contributes to the development of planning of various types of agricultural products, the formation of reasonable pricing, as well as the effective promotion of agricultural products in food markets. At the same time, it is necessary to ensure that all structural units achieve clearly defined goals, linking them with the general tasks of both the agricultural organization and the municipal agricultural industry as a whole. It is also more efficient to stimulate and coordinate municipal business in various areas and types of activity, while identifying alternative approaches and combinations of efficient distribution and use of the resource potential of all sources.

It shall also be noted that the target orientation of the above approaches in the first and third versions of the strategic formation of the municipal development of agricultural organizations will mainly contribute to the functioning of the goals of the fourth approach, therefore, it will be, on the one hand, an independent version of strategic development, and on the other, logical continuation of the previous approaches.

\section{References}

1. I. P. Borrelli, Agriculture and Agricultural Science Procedia, 8, 467-474 (2016) doi: 10.1016/j.aaspro.2016.02.046

2. A. Altukhov, A. Paptsov, A. Shut'kov, A. Semkin, et al., Main directions of accommodation and specialization of Russian agricultural sector: monograph, 348 (Moscow, Publishing house LLC Sam Poligrafist, 2020)

3. A. de Janvry, E. Sadoulet, World Development, 133, 105003 (2020) https://doi.org/10.1016/j.worlddev.2020.105003

4. T. Reardona, R. Echeverriab, J. Berdeguéc, B. Mintend, S. Liverpool-Tasiea, D. Tschirleya, D. Zilbermane, Agricultural Systems, 172, 47-59 (2019)

5. A. Semkin, Economy, labor, management in agriculture, 3, 63-70 (2020) doi: $10.33938 / 203-63$ 
6. A. Semkin, Improvement of AIC management model in the Russian Federation subjects, 213 (Moscow, Publishing house of the Center of international social and economic research in AIC of the Federal State Budgetary Scientific Institution "AllRussian Research Institute of Agricultural Economics", 2016)

7. S. J. Fielkea, R. Garrarda, E. Jakkua, A. Flemingb, L. Wisemanc, B. M. Taylor, NJAS - Wageningen Journal of Life Sciences, 90-91, $100296 \quad$ (2019) https://doi.org/10.1016/j.njas.2019.04.002

8. B. Talukder, A. Blay-Palmer, G. W. vanLoon, Keith W. Hipel, Environmental and Sustainability Indicators, 6, 100038 (2020) https://doi.org/10.1016/j.indic.2020.100038

9. E. Loizoua, C. Karelakisc, K. Galanopoulosd, K. Mattase, Agricultural Systems, 173, 482-490 (2019) https://doi.org/10.1016/j.agsy.2019.04.002

10. A. Altukhov, Russian food safety paradigm: monograph, 685 (Moscow, Fund "Candidate pool", 2019)

11. T. Tisenkopfs, A. Adamsone-Fiskovica, E. Kilis, S. Sumane, M. Grivins, T. PintoCorreia, H. Bjørkhaug, Global Food Security, 26, 100425 (2020) https://doi.org/10.1016/j.gfs.2020.100425

12. H. Gosnella, N. Gillb, M. Voyerc, Global Environmental Change, 59, 101965 (2019) https://doi.org/10.1016/j.gloenvcha.2019.101965

13. I. Coteura, F. Marchanda, L. Debruynea, F. Dalemansa, L. Lauwersa, Environmental $\begin{array}{lllll}\text { Impact Assessment } & \text { Review, } & \text { 69, } & 70-81 & \end{array}$ https://doi.org/10.1016/j.eiar.2017.12.003

14. J. Lankoskia, A. Thiemb, Ecological Economics, 178, 106809 (2020) https://doi.org/10.1016/j.ecolecon.2020.106809

15. G. Salimova, A. Ableeva, G. Khabirov, Z. Zalilova, G. Valieva, A. Hazieva, Journal of the Saudi Society of Agricultural Sciences, 19, 319-325 (2020) https://doi.org/10.1016/j.jssas.2020.03.001 